Tropical Journal of Pharmaceutical Research February 2012; 11 (1): 153-164

(C) Pharmacotherapy Group, Faculty of Pharmacy, University of Benin,

Benin City, 300001 Nigeria.

All rights reserved.

Available online at http://www.tjpr.org

Review Article

http://dx.doi.org/10.4314/tjpr.v11i1.20

\title{
Current Knowledge on Microarray Technology - An Overview
}

\section{Chitrala Kumaraswamy Naidu and Yeguvapalli Suneetha*}

Department of Zoology, Sri Venkateswara University, Tirupati -517502, India.

\begin{abstract}
The completion of whole genome sequencing projects has led to a rapid increase in the availability of genetic information. In the field of transcriptomics, the emergence of microarray-based technologies and the design of DNA biochips allow high-throughput studies of RNA expression in cell and tissue at a given moment. It has emerged as one of the most important technology in the field of molecular biology and transcriptomics. Arrays of oligonucleotide or DNA sequences are being used for genome-wide genotyping and expression profiling, and several potential clinical applications have begun to emerge as our understanding of these techniques and the data they generate improves. From its emergence to date, several database, software and technology updates have been developed in the field of microarray technology. This paper reviews basics and updates of each microarray technology and serves to introduce newly compiled resources that will provide specialist information in this area.
\end{abstract}

Keywords: Microarray, Databases, cDNA array, Oligonucleotide array 


\section{INTRODUCTION}

The completion of whole genome sequencing projects has led to a rapid increase in the availability of genetic information. In the field of transcriptomics, the emergence of microarray-based technologies and the design of DNA biochips allow high-throughput studies of RNA expression in cell and tissue at a given moment [1]. Today, microarray technology is one of the popular tools in molecular biology with its main advantage being that, unlike other traditional methods, it is not limited to investigating 'one gene at a time' [2].

In this review, we explain some of the fundamentals and recent updates on each microarray technology step-by-step. As it will be overwhelming to discuss all the updates of microarrays since its emergence, we have focused on the updates of the past few years. We intend also to expound on current knowledge of recent databases, data analysis software and some of the companies in the field of microarrays. We hope that an understanding of some of the fundamentals, recent updates and commercial technologies in microarrays will afford the beginner useful information in this area.

\section{MICROARRAY TECHNOLOGY}

Microarray is a technology which allows quantitative, simultaneous monitoring and expression of thousands of genes [3]. The basic principle behind microarray is the base complementarity, i.e., the base pair ' $A$ ' is complementary to ' $T$ ' and ' $C$ ' is complementary to 'G'. In a microarray, many thousands of spots are placed on a rectangular grid with each spot containing a large number of pieces of DNA from a particular gene. When the sample of interest contains many copies of mRNA, many bindings will occur, indicating that the gene from the transcribed mRNA is highly expressed. The quantity of hybridization can be determined because each copy of mRNA is labeled in the experiment with a fluorescent or radioactive tag and a brighter signal is detected when more copies bind [4]. In general, all microarray assays contain five discrete experimental steps - biological query, sample preparation, biochemical reaction, detection, data visualization and modeling [5]. According to Yuk Fai leung et al [6], a typical microarray experiment involves sample extraction, fluorescent labeling, cohybridization, scanning and finally statistical analysis. Microarray technologies can be broadly categorized into DNA microarrays and protein microarrays.

\section{DNA microarrays}

DNA microarrays provide a simple and natural vehicle for exploring the genome in a way that is both systematic and comprehensive. The power and universality of DNA microarrays as experimental tools derives from the exquisite specificity and affinity of complementary base-pairing [7]. DNA microarrays are of oligonucleotide arrays and a variety of cDNA arrays.

\section{Oligonucleotide arrays}

Oligonucleotide arrays or DNA chips are miniature parallel analytical devices containing libraries of oligonucleotides robotically spotted (printed) or synthesized in situ on solid supports (glass, coated glass, silicon or plastic) in a such way that the identity of each oligonucleotide is defined by its location [8]. Oligonucleotide arrays contain short fragments of DNA (25 base pairs). One of the commercially available oligonucleotide microarrays are the Gene Chips developed by firms such as Affymetrix. Ten to hundred thousands of different oligonucleotide probes are synthesized on each array. Traditionally, Affymetrix GeneChip Arrays are manufactured as a single array caged in a sealed cartridge with glass as a substrate.

The oligonucleotide technology pioneered by Affymetrix GeneChips differs from cDNA microarray in two important respects [9]. First, the probes are a set of 20-25 short 
oligonucleotides that are specific for each gene or exon, along with the related set with single base mismatches incorporated at the middle position of each oligonucleotide. These are synthesized in situ on each silicon chip using genome sequence information to guide photolithographic deposition. Second, the arrays are hybridized to a single biotinylated amplified RNA sample, and the intensity measure for each gene is computed by an algorithm that messages the difference between the match and mismatch measurements, and averages over each oligonucleotide. Key difference between gene chips and a cDNA microarray is the way genes are represented on the arrays. In in situ photolithographic synthesis method used by Affymetrix gene chip probe arrays, the quality of chips produced depends critically on the efficiency of photo-deprotection [10].

There are many other advantages to oligonucleotide-based microarrays. The quality and reproducibility of printed oligonucleotide arrays ("print format") are superior [11]. Although there is a large initial capital outlay to purchase large sets of oligonucleotides, the printed arrays are inexpensive on a unit basis. Furthermore, long oligonucleotide probes can be synthesized directly on an array surface (photo printed arrays). In either case, whether printed or photo printed, the composition of the array can be absolutely specified and hence is completely reproducible by others. A limitation of oligonucleotide arrays is the requirement of relatively large amounts of biological starting materials for gene expression analysis [12]. GE Healthcare, Ocimum Biosolutions, and Agilent are some of the other companies which provide commercially available designs of Oligonucleotide microarrays.

\section{cDNA arrays}

cDNA arrays contain long fragments of DNA (from 100 to thousands of base pairs). cDNA arrays are created by robotically spotting individual samples of purified cDNA clones onto a solid support (glass slide or membrane). Some of the basic principles behind preparation of cDNA arrays includes: i) selection of the targets to be printed on the array directly from databases such as GenBank, dbESt, and UniGene or randomly from any library of interest; ii) arraying the selected cDNA targets onto the known location of coated glass microscope slide using a computer-controlled high speed robot; iii) fluorescently labeling the total RNA from both test and reference samples using dyes with a single round of reverse transcription; iv) pooling the florescent target for hybridization under stringent conditions; v) measuring the laser excited incorporated targets using a scanning confocal laser microscope; and v) finally, analyzing the images from scanner by importing into a software in which they are pseudo-colored and merged. Micro spotting, piezoelectric printing and photolithography (an 'in situ' fabrication technique developed by Affymetrix) are some of the techniques used for arraying cDNA. Invitrogen, Genome systems, Biodiscovery, Xeno, Affymetrix, Silicon genetics, Genetix, etc., are some of the companies which produce commercial arrayers. Open GMS 418 Array Scanner, GeneChip ${ }^{8} \quad$ Scanner $3000 \quad$ System (Affymetrix), DNA Microarray Scanner (Agilent), Typhoon Variable Mode Imager (GE Healthcare), InnoScan 700( INNOPSIS), Axon GenePix4000ALMicroarray scanner (Molecular Devices), and PowerScanner (Tecan) are some of the commercial scanning devices which detect different levels of fluorescence between the spots on the microarray. Apart from applications of cDNA array in comparative genome analysis and functional genome analysis, recent applications include gene expression profiling of drug-resistant small cell lung cancer cells [13], characterization of osmotic stressinduced genes in poplar cells [14] and veterinary diagnostics.

\section{Protein microarray}

Trop J Pharm Res, February2012;11 (1):155 
Though DNA microarray is very useful, it has several limitations. The expression levels of many genes are subject to significant posttranscriptional regulation and many proteins are grossly affected by post-translational modification such as phosphorylation, glycosylation, acetylation, proteolysis etc. Obviously, a nucleic acid-based array is blind to such effects and for certain applications, the tedious sample preparation requirements of DNA microarrays make them impractical [15]. The solution for this is to analyze proteins rather than make inferences based on RNA levels directly which can be done through protein microarrays. Protein microarrays also known as protein chips are nothing but grids that contain small amounts of purified proteins in ahigh density. The proteins can be screened in a highthroughput fashion for biochemical activity, protein-protein, protein-DNA, protein-RNA and protein-ligand interactions [16]. The common element for each type of microarray, whether it is tissue array or antibody array or protein arrays, is the immobilization of bait molecules on a substratum, either as a homogeneous or heterogeneous spot. Bait molecules may be aptamers, antibodies, cell lysates, phage or recombinant protein/peptide, a nucleic acid, or a tissue depending upon the type of microarray. The capture molecule may be a complex biologic mixture, such as serum or a cell lysate, an antibody or ligand [17]. The substratum can be glass slides, porous gel slides and microwells.

Protein microarrays can be major categorized into three types [18]: analytical microarrays, functional microarrays, and reverse phase microarrays. Analytical microarrays are the ones in which biomolecular recognition molecules are immobilized on a heterogeneous matrix using micro printing or micro structuring process. Hapten and antibody microarrays are some of the most common analytical microarrays. Among the several subgroups of protein biochips such as peptide arrays, antibody arrays, cell based arrays, etc, antibody arrays are the widely used ones. In antibody microarrays, bait molecules are numerous individual antibodies ( $<500$ antibodies/array) which act as probes for the targeted protein analytes immobilized on a surface. This surface can be glass or ceramic base as in the case of CombiMatrix ElectraSense microarray.

The main problems with antibody-mediated analytical protein microarrays are specificity, quantization and most of the antibodies cross-react with proteins other than the antigen of interest which leads to poor quantification. Clontech, Eurogentec, Labvision corporation, Arrayit, Sigma Life sciences, Abnova, etc, are some of the companies which prepare antibody arrays. Among these, Abnova is the largest manufacturer of antibody arrays with 41 products. Current antibody microarray designs provide a unique tool for rapid, sensitive and selective profiling of crude, nonfractionated proteomes, targeting upto hundreds of protein analytes in one experiment [19], e.g., Clontech's "Ab Microarray 500" technology allows profiling of 507 antibodies in a one-day experiment. In recent years, these antibody microarrays play a key role for specific detection of bioterrorism agents, as exemplified by ricin, cholera toxin (CT) and staphylococcal enterotoxin B (SEB) [20]. Some of the companies which prepare antibody arrays, along with their products, are listed in Table 1.

The second type of microarray is functional protein microarrays which are composed of arrays containing full-length functional proteins or protein domains. These spotted arrays are used to probe the function or binding properties of native proteins. Functional protein microarrays have been successfully applied to identify proteinprotein, protein-small molecule and proteinDNA interactions to reveal or characterize enzymatic activities of proteins.

Trop J Pharm Res, February2012;11 (1):156 
Table 1: Summary of antibody microarray firms

\begin{tabular}{|c|c|c|}
\hline Firm & Technology & Comments \\
\hline Affymetrix & $\begin{array}{l}\text { Human Cytokine } \\
\text { Antibody Array } \\
\text { EXPANDED ver } 3.0\end{array}$ & $\begin{array}{l}\text { Facilitates, simultaneous detection of multiple human } \\
\text { cytokines from a variety of sources, including cell lysates, } \\
\text { conditioned media, patient sera, plasma and urine. }\end{array}$ \\
\hline Clontech & $\begin{array}{l}\text { Antibody Microarrays } \\
380 \& 500\end{array}$ & Screens 380 or 507 antibodies in one day. \\
\hline $\begin{array}{l}\text { Full Moon } \\
\text { Biosystems }\end{array}$ & $\begin{array}{l}\text { Phospho Explorer S1 } \\
\text { Antibody Array }\end{array}$ & $\begin{array}{l}\text { Consists of } 562 \text { well-characterized phospho-specific } \\
\text { antibodies, a subset of the Phospho Explorer Array } \\
\text { (PEX100). It allows researchers to study and analyze } \\
\text { hundreds of commonly examined proteins on a single } \\
\text { slide. }\end{array}$ \\
\hline $\begin{array}{l}\text { Gentel } \\
\text { Biosciences }\end{array}$ & $\begin{array}{l}\text { APiX Profiling } \\
\text { Antibody Arrays }\end{array}$ & $\begin{array}{l}\text { Simultaneously profile the relative concentration of up to } \\
97 \text { cytokines and related proteins. }\end{array}$ \\
\hline Hypromatrix & $\begin{array}{l}\text { Signal Transduction } \\
\text { AntibodyArray }\end{array}$ & $\begin{array}{l}\text { Each Signal Transduction AntibodyArray contains } 400 \text { high } \\
\text { quality antibodies against well-studied signaling proteins. }\end{array}$ \\
\hline MicroBioChips & Plasmascan 380 & $\begin{array}{l}\text { Targets } 380 \text { native and low-abundant human serum } \\
\text { proteins. }\end{array}$ \\
\hline RayBiotech, Inc & $\begin{array}{l}\text { RayBio Antibody Array } \\
\text { G Series }\end{array}$ & $\begin{array}{l}\text { The principle of } G \text { series antibody arrays (glass slide } \\
\text { based antibody arrays) is similar to membrane-based } \\
\text { antibody arrays. Scientists can detect the expression of } \\
174 \text { cytokines in a single experiment. }\end{array}$ \\
\hline R\&D Systems & $\begin{array}{l}\text { Proteome Profiler } 96 \\
\text { Microplate-based } \\
\text { Antibody Arrays }\end{array}$ & $\begin{array}{l}\text { Proteome Profiler } 96 \text { Antibody Arrays are } 96 \text {-wel } \\
\text { microplate-based assays with up to } 16 \text { antibodies per wel } \\
\text { for simultaneous detection of multiple analytes. }\end{array}$ \\
\hline $\begin{array}{l}\text { Sigma Life } \\
\text { sciences }\end{array}$ & $\begin{array}{l}\text { Panorama }{ }^{\circledR} \text { Antibody } \\
\text { Array }\end{array}$ & $\begin{array}{l}\text { Contains } 224 \text { human antibodies to key cellular proteins } \\
\text { with a special emphasis on cell signaling proteins. }\end{array}$ \\
\hline US Biomax, Inc & $\begin{array}{l}\text { Explorer Antibody } \\
\text { Array }\end{array}$ & $\begin{array}{l}\text { Allows investigators to examine their samples against } 656 \\
\text { antibodies in a single experiment. }\end{array}$ \\
\hline
\end{tabular}

The most promising task in functional microarray is fabrication of proteins in functional form or correctly folded form. Recent advances in fabrication of proteins include atmospheric pressure plasma (AP) treatment technique [21], surface-attached hydrogel microstructures in high concentrations [22], etc. The third type of microarray is reverse phase protein microarray (RPA). Unlike functional and antibody arrays, these RPA involves the immobilization of all proteins present in an individual tissue or cell population instead of a single probe. Some of the recent applications of RPA include understanding the pathobiology of complex disorders such as cancer, stroke and traumatic brain injury [23], identifying novel anti-invasion mechanisms and anti-metastatic activities, e.g., 3-(50-hydroxymethyl-20-furyl)1-benzyl-indazole [24], quantitative analysis of down regulated genes, disease progression and in discovering biomarkers.

Detection strategies of Protein microarrays on the other hand can be of (1) label-free methods and (2) labeled probe methods. Label-free methods are mass spectrometry, surface plasmon resonance imaging (SPR) and atomic force microscopy. Labeled probe detection methods are of three types i.e., direct, indirect and sandwich. In direct detection strategies, a labeled probe directly binds to the target molecule immobilized on a substratum. Amplification strategies based on 
avidin-biotin binding enhance the sensitivity of detection in direct detection methods. In, indirect detection strategies an immobilized probe is used for capturing labeled, specific molecules from a complex mixture of query molecules. In Sandwich assays, two distinct probes are used for detection of a capture molecule. The first probe is immobilized on the substratum and the molecule of interest binds to its cognate probe. A second, labeled probe detects the bound probe-capture molecule complex.

\section{MICROARRAY DATA ANALYSIS}

Microarray technologies generate huge amount of data. A typical microarray data set includes expression levels for thousands of genes across hundreds of conditions. Converting the data provided in a microarray dataset into meaningful biological information involves several steps including [25]: i) normalization ii) prediction of differentially expressed genes using comparison statistics iii) identification and partition of expression patterns based on up and down regulation, magnitude and clustering of genes iv) summarizing the identified gene expression patterns using gene annotation tools, and v) deriving the biological significance of summarized genes using ontology report or pathway report. Precise microarray data analysis involves quality control, normalization, statistical analysis, clustering and classification.

Quality control involves, background correction and filtering to include only positive values above the background. ERCC (External RNA Control Consortium), The Norwegian Microarray Consortiums (NMC) and MAQC (Microarray Quality Control) project are some of the groups which aim to provide quality control (QC) tools to the microarray community for avoiding procedural failures. Multicheck, LaserCheck, QC Pac 1, and Simpleaffy are some of the commercial software packages provided by companies such as Tecan Group Ltd and Affymetrix, and are used for quality control.
Normalization or scaling involves conversion of raw data into normalized or scaled data. It is an important step for microarray data analysis to minimize biological and technical variations. Gene Expression Pattern Analysis Suite (GEPAS) and Ginkgo are some of the software used for normalization of microarray data. Statistical analysis or calculating differential expression involves controlling the false positives, selecting a significant cutoff, multiple testing correction, etc. Clustering, on the other hand, is nothing but, unsupervised grouping of similar profiles together based on a distance metric while supervised grouping is called classification. CAGED and DNA-chip analyzer are some of the software used for clustering analysis. Some of the software that are used at various stages of microarray data analysis are illustrated in the Figure 1 while a short description of these software is provided in the Table 2.

\section{MICROARRAY DATABASES}

A huge amount of data obtained through microarray technologies analyzed as described above are maintained in two ways [47]: (a) using a software, usually installed locally, that allows storage, querying and analysis of data captured on-site, and (b) databases that act as repositories for publicly available data, in particular, published data. Three important elements to be considered for sharing microarray data are i) a data annotation standard ii) a common data exchange format, and iii) public repositories analogous to DDBJ/EMBL/GenBank. The common microarray data standard used is Minimum Information About a Microarray Experiment (MIAME) and the standard data exchange format is Microarray Gene Expression Markup Language (MAGE-ML) which is an XML based data exchange format developed by Microarray Gene Expression Data (MGED) Society and Object Management Group (OMG) [48]. In Table 3 some of the recent database repositories and data management systems have been surmmarised as it would well be beyond the 


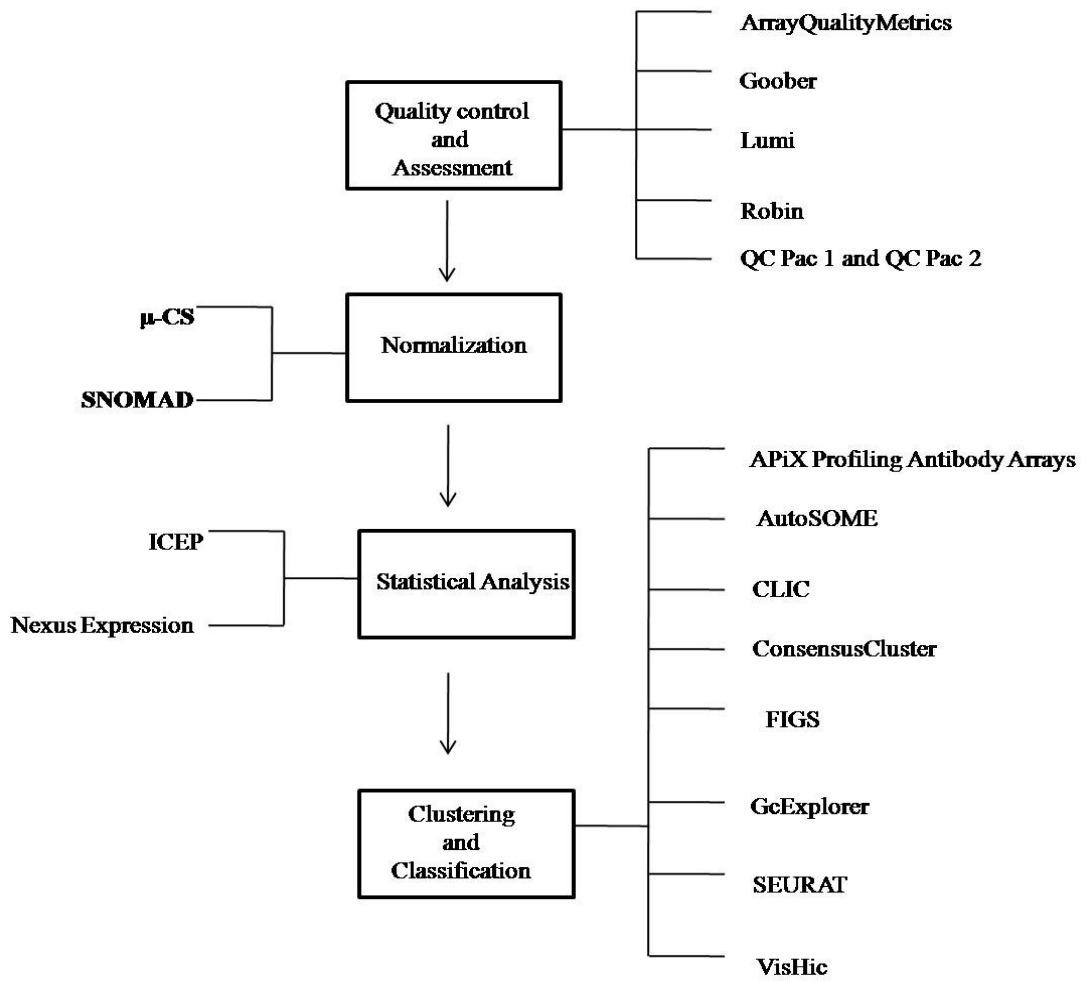

Figure 1: Various software used in microarray data analysis

Table 2: Summary of microarray data analysis software

\begin{tabular}{|c|c|c|c|}
\hline Category & Software & Comments & References \\
\hline & $\begin{array}{l}\text { ArrayQuality- } \\
\text { Metrics }\end{array}$ & $\begin{array}{l}\text { Bioconductor package used for assessing the } \\
\text { quality and identifying apparent outlier arrays. }\end{array}$ & [26] \\
\hline & Goober & $\begin{array}{l}\text { Software package available to help critical } \\
\text { tasks, such as data quality control and } \\
\text { inventory management. }\end{array}$ & [27] \\
\hline & Lumi & $\begin{array}{l}\text { It is a bioconductor package especially } \\
\text { designed to process the Illumina microarray } \\
\text { data which includes data input, quality } \\
\text { control, variance stabilization, normalization } \\
\text { and gene annotation portions. }\end{array}$ & [28] \\
\hline \multirow[t]{2}{*}{$\begin{array}{l}\text { Quality control and } \\
\text { assessment }\end{array}$} & Robin & $\begin{array}{l}\text { It is a noncommercial, easy-to-use graphical } \\
\text { application. Provides functions for thorough } \\
\text { quality assessment of the data and } \\
\text { automatically generates warnings to notify the } \\
\text { user of potential outliers, low-quality chips, or } \\
\text { low statistical power. }\end{array}$ & [29] \\
\hline & $\begin{array}{l}\text { QC Pac } 1 \\
\text { and QC Pac } \\
2\end{array}$ & $\begin{array}{l}\text { Comprehensive quality control package for } \\
\text { Tecan's absorbance readers. }\end{array}$ & [30] \\
\hline
\end{tabular}


Table 2: Summary of microarray data analysis software (contd)

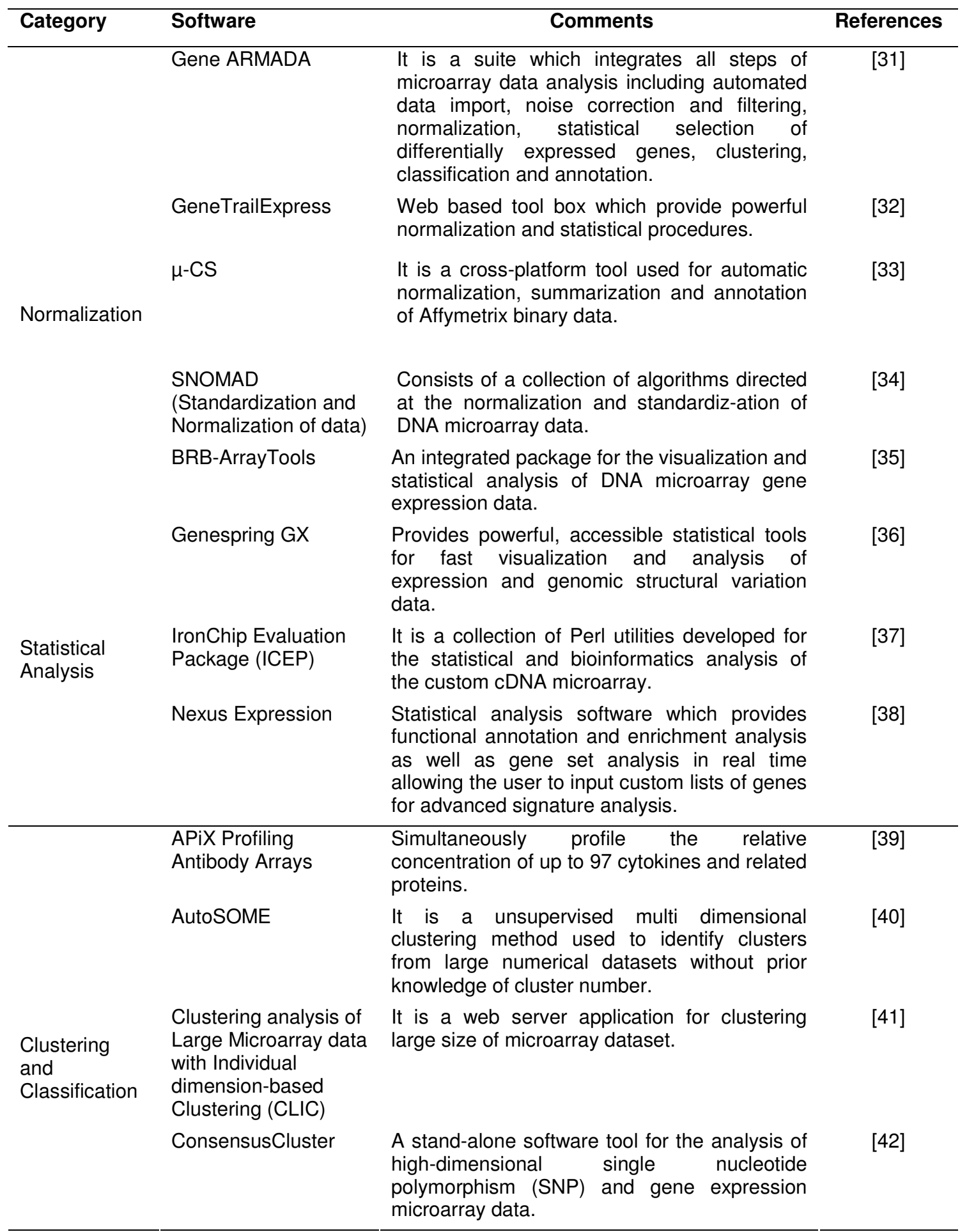


Table 2: Summary of microarray data analysis software (contd)

\begin{tabular}{|c|c|c|c|}
\hline Category & Software & Comments & References \\
\hline $\begin{array}{l}\text { Clustering } \\
\text { and }\end{array}$ & $\begin{array}{l}\text { Filter-based } \\
\text { Gene } \\
\text { Selection } \\
\text { (FIGS) }\end{array}$ & $\begin{array}{l}\text { It is a web-based workbench where user can } \\
\text { conveniently compare the classification performances } \\
\text { of many different filter-based gene selection } \\
\text { procedures. }\end{array}$ & [43] \\
\hline $\begin{array}{l}\text { Classification } \\
\text { (contd) }\end{array}$ & GcExplorer & $\begin{array}{l}\text { A tool to visualize cluster results and investigate } \\
\text { additional properties of clusters using interactive } \\
\text { neighborhood graphs. }\end{array}$ & [44] \\
\hline & SEURAT & $\begin{array}{l}\text { It is a software tool which provides interactive visualiza- } \\
\text { tion for the integrated analysis of high-dimensional gene } \\
\text { expression data and performs clustering. }\end{array}$ & [45] \\
\hline $\begin{array}{l}\text { Clustering } \\
\text { and } \\
\text { Classification }\end{array}$ & VisHic & $\begin{array}{l}\text { It is a public web server for clustering and interpreting } \\
\text { gene expression data. Performs the labor-intensive task } \\
\text { of evaluating hundreds of redundant clusters in a rapid } \\
\text { automated manner. }\end{array}$ & [46] \\
\hline
\end{tabular}

Table 3: Summary of Microarray Databases

\begin{tabular}{|c|c|c|}
\hline Database & Comment & References \\
\hline aeGEPUCI & $\begin{array}{l}\text { aeGEPUCI is a publicly-accessible database and data-mining tool, that } \\
\text { integrates microarray analyses of sex- and stage-specific gene } \\
\text { expression in Ae. aegypti. }\end{array}$ & [49] \\
\hline ANEXdb & $\begin{array}{l}\text { ANEXdb (an integrated animal ANnotation and microarray EXpression } \\
\text { database) is an open-source web application that supports integrated } \\
\text { access of two databases that house microarray expression (ExpressDB) } \\
\text { and EST annotation (AnnotDB) data. Currently supports storage and } \\
\text { querying of Affymetrix-based expression data as well as retrieval of } \\
\text { experiments in a form ready for NCBI-GEO submission. }\end{array}$ & [50] \\
\hline GATExplorer & $\begin{array}{l}\text { GATExplorer (Genomic and Transcriptomic Explorer) is a database and } \\
\text { web platform that integrates a gene loci browser with nucleotide level } \\
\text { mappings of oligo probes from expression microarrays. }\end{array}$ & [51] \\
\hline $\begin{array}{l}\text { Microarray } \\
\text { meta- } \\
\text { analysis } \\
\text { database } \\
\left(\mathrm{M}^{2} \mathrm{DB}\right)\end{array}$ & $\begin{array}{l}M^{2} D B \text { is a human curated microarray database designed for easy } \\
\text { querying based on clinical information and for interactive retrieval of } \\
\text { either raw or uniformly pre-processed data, along with a set of quality- } \\
\text { control metrics. The database contains more than } 10,000 \text { previously } \\
\text { published Affymetrix GeneChip arrays, performed using human clinical } \\
\text { specimens. }\end{array}$ & [52] \\
\hline OligoArrayDb & $\begin{array}{l}\text { OligoArrayDb is a comprehensive database containing pangenomic } \\
\text { oligonucleotide microarray probe sets designed for most of the } \\
\text { sequenced genomes that are not covered by commercial catalog arrays. } \\
\text { Contains more than } 2.8 \text { probes per gene in average for more than } 600 \\
\text { organisms, mostly archaea and bacteria strains available from public } \\
\text { database. }\end{array}$ & [53] \\
\hline PathEx & $\begin{array}{l}\text { PathEx main goal was to develop a novel concept to offer less exploited } \\
\text { opportunities for the analysis of deposited microarray data. Deposited } \\
\text { microarray data comes with description files. These metadata files } \\
\text { contain some key information that can be used to link the microarray } \\
\text { data to other biologically related information. }\end{array}$ & {$[54]$} \\
\hline
\end{tabular}


scope of this article to review all the software and database repositories for microarray technologies, which have been thoroughly reviewed elsewhere [47].

\section{CONCLUSION}

Microarrays are one of the excellent highthroughput technologies in the field of genomics and proteomics. Over the past decade, these microarrays have emerged as outstanding tools in molecular biology. In the near future, these may satisfy the rising needs of the scientific community to relate genetic pattern to disease.

\section{REFERENCES}

1. Gardiner-Garden M, Littlejohn TG. A comparison of microarray databases. Brief Bioinform. 2001; 2(2) : 143-158.

2. Georgii E, Richter L, Ruckert U, Kramer $S$. Analyzing microarray data using quantitative association rules. Bioinformatics. 2005; 21 Suppl 2: ii123-129.

3. Afshari CA. Perspective: microarray technology, seeing more than spots. Endocrinology. 2002; 143(6): 1983-1989.

4. Kuo WP, Whipple ME, Jenssen TK, Todd R, Epstein JB, Ohno-Machado L, Sonis ST, Park $P J$. Microarrays and clinical dentistry. J Am Dent Assoc. 2003; 134(4): 456-462.

5. Schena $M$, Heller RA, Theriault TP, Konrad $K$, Lachenmeier E, Davis RW. Microarrays: biotechnology's discovery platform for functional genomics. Trends Biotechnol. 1998; 16(7): 301-306.

6. Leung YF, Cavalieri D. Fundamentals of $c D N A$ microarray data analysis. Trends Genet. 2003; 19(11): 649-659.

7. Brown PO, Botstein D. Exploring the new world of the genome with DNA microarrays. Nat Genet. 1999; 21(1 Suppl): 33-37.

8. Tillib SV, Mirzabekov AD. Advances in the analysis of DNA sequence variations using oligonucleotide microchip technology. Curr Opin Biotechnol. 2001; 12(1): 53-58.

9. Gibson G. Microarrays in ecology and evolution: a preview. Mol Ecol. 2002; 11(1): 17-24.

10. Beier M, Hoheisel JD. Production by quantitative photolithographic synthesis of individually quality checked DNA microarrays. Nucleic Acids Res. 2000; 28(4): E11.

11. Lucito R, Healy J, Alexander J, Reiner A, Esposito $D$, Chi M, Rodgers L, Brady A, Sebat J, Troge $J$, West JA, Rostan S, Nguyen KCQ, Powers $S$, Ye $K Q$, Olshen A, Venkatraman E, Norton L, Wigler M . Representational oligonucleotide microarray analysis: a high-resolution method to detect genome copy number variation. Genome Res. 2003; 13(10): 2291-2305.

12. Ji W, Zhou W, Gregg K, Lindpaintner K, Davis S. A method for gene expression analysis by oligonucleotide arrays from minute biological materials. Anal Biochem. 2004; 331(2): 329339.

13. Guo L, Liu Y, Bai Y, Sun Y, Xiao F, Guo Y. Gene expression profiling of drug-resistant small cell lung cancer cells by combining microRNA and cDNA expression analysis. Eur $J$ Cancer. 2010; 46(9): 1692-1702.

14. Bae EK, Lee H, Lee JS, Noh EW. Isolation and characterization of osmotic stress-induced genes in poplar cells by suppression subtractive hybridization and cDNA microarray analysis. Plant Physiol Biochem. 2010; 48(23): 136-141.

15. Kodadek T. Protein microarrays: prospects and problems. Chem Biol. 2001; 8(2): 105-115.

16. Zhu $H$, Snyder M. Protein arrays and microarrays. Curr Opin Chem Biol. 2001; 5(1): 40-45.

17. Espina V, Woodhouse EC, Wulfkuhle J, Asmussen $H D$, Petricoin EF, 3rd, Liotta LA. Protein microarray detection strategies: focus on direct detection technologies. J Immunol Methods. 2004; 290(1-2): 121-133.

18. Hall DA, Ptacek J, Snyder M. Protein microarray technology. Mech Ageing Dev. 2007; 128(1): 161-167.

19. Borrebaeck CA, Wingren C. Design of high-density antibody microarrays for disease proteomics: key technological issues. J Proteomics. 2009; 72(6): 928-935.

20. Lian W, Wu D, Lim DV, Jin S. Sensitive detection of multiplex toxins using antibody microarray. Anal Biochem. 2010; 401(2): 271-279.

21. Lee $K$, Shin JY, Yang YS, Shin Jl, Park YC, Seo $J H$, Park TH, Shin CS, Jin YS, Kweon DH. Towards a microarray of functional membrane proteins: Assembly of a surface-attachable, membrane protein-anchored membrane structure using apolipoprotein A-1. Enzyme Microb Technol. 2009; 2(44): 217-222.

22. Moschallski M, Baader J, Prucker O, Ruhe J. Printed protein microarrays on unmodified plastic substrates. Anal Chim Acta. 2010; 671(1-2): 92-98.

23. Gyorgy $A B$, Walker $J$, Wingo $D$, Eidelman $O$, Pollard HB, Molnar A, Agoston DV . Reverse phase protein microarray technology in traumatic brain injury. J Neurosci Methods. 2010; 192(1): 96-101.

24. Hong B, Lui VW, Hui EP, Lu Y, Leung HS, Wong EYL, Cheng SH, Ng MHL, Mills GB, Chan ATC . Reverse phase protein array identifies novel anti-invasion mechanisms of $\mathrm{YC}-1$. Biochem Pharmacol. 2010; 79(6): 842-852.

25. Olson NE. The microarray data analysis process: from raw data to biological significance. NeuroRx. 2006; 3(3): 373-383.

26. Kauffmann $A$, Gentleman $R$, Huber $W$. arrayQualityMetrics--a bioconductor package 
for quality assessment of microarray data. Bioinformatics. 2009; 25(3): 415-416.

27. Luo W, Gudipati M, Jung K, Chen M, Marschke KB. Goober: a fully integrated and user-friendly microarray data management and analysis solution for core labs and bench biologists. $J$ Integr Bioinform. 2009; 6(1): 108.

28. $D u$ P, Kibbe WA, Lin SM. lumi: a pipeline for processing Illumina microarray. Bioinformatics. 2008; 24(13): 1547-1548.

29. Lohse $M$, Nunes-Nesi $A$, Kruger $P$, Nagel $A$, Hannemann J, Giorgi FM, Childs L, Osorio S, Walther D, Selbig J, Sreenivasulu N, Stitt M, Fernie AR, Usadel B. Robin: an intuitive wizard application for $R$-based expression microarray quality assessment and analysis. Plant Physiol. 2010; 153(2): 642-651.

30. QC Pac 1 and QC Pac [http://www.tecan.com]

31. Chatziioannou A, Moulos P, Kolisis FN. Gene ARMADA: an integrated multi-analysis platform for microarray data implemented in MATLAB. BMC Bioinformatics. 2009; 10: 354.

32. Keller A, Backes C, Al-Awadhi M, Gerasch A, Kuntzer J, Kohlbacher O, Kaufmann M, Lenhof HP. GeneTrailExpress: a web-based pipeline for the statistical evaluation of microarray experiments. BMC Bioinformat 2008; 9: 552.

33. Guzzi PH, Cannataro M. mu-CS: an extension of the TM4 platform to manage Affymetrix binary data. BMC Bioinformatics. 2010; 11: 315.

34. Colantuoni C, Henry G, Zeger S, Pevsner J. SNOMAD (Standardization and NOrmalization of MicroArray Data): web-accessible gene expression data analysis. Bioinformatics. 2002; 18(11): 1540-1541.

35. Simon R, Lam A, Li MC, Ngan M, Menenzes S, Zhao $Y$. Analysis of gene expression data using BRB-ArrayTools. Cancer Inform. 2007; 3: 11-17.

36. GeneSpring Gx [http://chem.agilent.com/]

37. Vainshtein $Y$, Sanchez M, Brazma A, Hentze MW, Dandekar T, Muckenthaler MU. The IronChip evaluation package: a package of perl modules for robust analysis of custom microarrays. BMC Bioinformat 2010; 11: 112.

38. Nexus Expression [http://www.biodiscovery.com/I ndex/nexus-expression]

39. APiX Profiling Antibody Arrays [http://www.gentel bio.com/]

40. Newman AM, Cooper JB. AutoSOME: a clustering method for identifying gene expression modules without prior knowledge of cluster number. BMC Bioinformatics. 2010; 11: 117.

41. Yun T, Hwang T, Cha K, Yi GS. CLIC: clustering analysis of large microarray datasets with individual dimension-based clustering. Nucleic Acids Res. 2010; 38(Web Server issue): W246-W253.

42. Seiler M, Huang CC, Szalma S, Bhanot G. ConsensusCluster: a software tool for unsupervised cluster discovery in numerical data. OMICS. 2010; 14(1): 109-113.
43. Hwang $T$, Sun $C H$, Yun T, Yi GS. FiGS: a filterbased gene selection workbench for microarray data. BMC Bioinformat 2010; 11: 50.

44. Scharl T, Voglhuber I, Leisch F. Exploratory and inferential analysis of gene cluster neighborhood graphs. BMC Bioinformatics. 2009; 10: 288-318.

45. Gribov A, Sill M, Luck S, Rucker F, Dohner K, Bullinger L, Benner A, Unwin A. SEURAT: visual analytics for the integrated analysis of microarray data. BMC Med Genomics. 2010; 3 (1): 21.

46. Krushevskaya $D$, Peterson $H$, Reimand $J$, Kull M, Vilo J. VisHiC--hierarchical functional enrichment analysis of microarray data. Nucleic Acids Res. 2009; 37(Web Server issue): W587-W592.

47. Penkett CJ, Bahler J. Navigating public microarray databases. Comp Funct Genomics. 2004; 5(67): 471-479.

48. Brazma A, Parkinson $H$, Sarkans $U$, Shojatalab $M$, Abeygunawardena $N$, Contrino $S$, Coulson $R$, Farne A, Garcia Lara G, Holloway E, Kapushesky M, Lilja $P$, Mukherjee G, Oezcimen A, Rayner $T$, Rocca Serra A, Sharma A, Sansone $S$. ArrayExpress--a public repository for microarray gene expression data at the EBI. Nucleic Acids Res. 2003; 31(1): 68-71.

49. Dissanayake SN, Ribeiro JM, Wang MH, Dunn WA, Yan G, James AA, Marinotti O. aeGEPUCl: a database of gene expression in the dengue vector mosquito, Aedes aegypti. BMC Res Notes. 2010; 3: 248.

50. Couture O, Callenberg K, Koul N, Pandit S, Younes $R$, Hu ZL, Dekkers J, Reecy J, Honavar V, Tuggle C. ANEXdb: an integrated animal ANnotation and microarray EXpression database. Mamm Genome. 2009; 20(11-12): 768-777.

51. Risueno A, Fontanillo C, Dinger ME, De Las Rivas J. GATExplorer: genomic and transcriptomic explorer; mapping expression probes to gene loci, transcripts, exons and ncRNAs. BMC Bioinformatics. 2010; 11: 221.

52. Cheng WC, Tsai ML, Chang CW, Huang CL, Chen CR, Shu WY, Lee YS, Wang TH, Hong JH, Li CY, Hsu IC. Microarray meta-analysis database $(M(2) D B)$ : a uniformly preprocessed, quality controlled, and manually curated human clinical microarray database. BMC Bioinformatics. 2010; 11: 421.

53. Rouillard JM, Gulari E. OligoArrayDb: pangenomic oligonucleotide microarray probe sets database. Nucleic Acids Res. 2009; 37(Database issue): D938-D941.

54. Bareke E, Pierre M, Gaigneaux A, De Meulder B, Depiereux S, Berger F, Habra N, Depiereux E. PathEx: a novel multi factors based datasets selector web tool. BMC Bioinformatics. 2010; 11: 528. 
Naidu \& Suneetha

Trop J Pharm Res, February2012;11 (1):164 